\title{
"Such a Site for Play, This Edge": \\ Surfing, Tourism, and Modernist Fantasy \\ in Papua New Guinea
}

Paige West

\begin{abstract}
At 3:00 Am on 2I December 2007, I found myself standing, fully clothed, in a freezing shower on the island of Nusa Lik in New Ireland Province, Papua New Guinea, holding the head of an Australian teenager as he vomited on my bare feet. He, along with his father, his father's "mates," and their sons, had been drinking for the entire day. A friend of mine who works at the Nusa Island Retreat had tasked me with looking after the young man. As a woman, I was thought to be able to provide a calming, somewhat motherly influence. In fact, my presence, as an anthropologist, incited the young man to say, between gasps for air and the expelling of copious amounts of vomit, "It's just so, you know, man, so real. It's so real here. .. . I mean they are just so, like, they just live. . . . It's just, like, a man and his hut and the sea and the waves, like, forever. . . I'm never going back home."

The young man had accompanied eight other men on a surf holiday to Papua New Guinea. They were all Australians, from Brisbane and other smaller Gold Coast towns, and they were all very accomplished surfers. While on Nusa Lik Island, they surfed, drank astounding quantities of South Pacific Lager brown bottles and Bundaberg Rum, fished, ate, and then surfed and drank more. And they enjoyed every second of it. Earlier in the day, prior to my unexpected shower, I had spent several hours with the young man, whom I will call Brendan, poring over international surfrelated magazines and talking about Papua New Guinea, anthropology, and his future. Brendan, his father, and their friends exemplify the people who come to Papua New Guinea as surf tourists. They are male, they have visited multiple surf-tourism destinations, they are from Australia, they
\end{abstract}

The Contemporary Pacific, Volume 26, Number 2, 4II-432

(C) 2014 by University of Hawai'i Press 
are between the ages of twenty and sixty, they are voracious consumers of surf-related media, and they all identify themselves as "surfers."

In this article, I examine the relationships between the production and circulation of print media, the production of ideas about people and places, and masculine self-fashioning, as these processes are enacted with regard to surfing in the Melanesian Pacific. I argue that the surf tourism industry depends on and then reproduces fantasies about the relationship between primitive and civilized peoples, places, and times, as well as particular notions about "discovery" and "the frontier," and I show that surfing as sport tourism becomes another avenue for the reproduction of modernist forms and ideas about Western selves and "others."

In making my argument, I draw on ethnographic fieldwork and participant observation in New Ireland Province, Papua New Guinea; ${ }^{1}$ survey data collected from 239 surf tourists who have visited Papua New Guinea; ${ }^{2}$ e-mail-administered interviews with 45 surf tourists who have visited Papua New Guinea; ${ }^{3}$ and textual analysis of surf-related magazines. The article attends to the fantasy and tourism lives of men because the vast majority of surfers who come to Papua New Guinea are male. Women surf tourists tend not to visit Papua New Guinea. Of the 239 people surveyed, 8 were women. Of the 45 surf tourists interviewed by e-mail, 5 were women. During my ethnographic fieldwork in New Ireland, only 9 surfers I encountered were women.

\section{Surf TOURISM}

In 20I0, there were 935 million arrivals at tourism destinations globally (UNWTO 2OII). Surf tourism, one of the most robust sectors of the tourism industry, is the economic linchpin for the global surf industry (Kampion 2003; Warshaw 2004). The industry, which caters to ten million surfers, is a multibillion-dollar business that includes the production of commodities like surfboards and clothing, the distribution of those commodities, and the organization of professional sporting events like the Rip Curl Pro and the Quicksilver Pro (see Buckley 2006, 407; Reed 1999). It also features multiple forms of tourism, including high-end resort tourism and ecotourism. All tourism depends on mediated images to drive consumer desire (Urry 2002; see also Croy and others 2009; Foale and Macintyre 2005). The surf-tourism industry depends on both its own internal, industry generated and owned media-like surf magazines, "documentaries," and websites—and externally produced media, like surfing movies (Beat- 
tie 2001; Buckley 2003; Henderson 1999; Ormond 2005; Ponting 2009; Rutsky 1999). The media associated with surfing produces images of certain kinds of people and particular types of places. The people are, overwhelmingly, white male surfers, cast as brave and intrepid explorers who are carefree, alternative minded, and nonconformist. The places are some combination of exotic, uninhabited (or lightly inhabited), undiscovered (or recently discovered) sites with perfect waves, a chance of danger or intrigue, beautiful bikini-clad women, and uncrowded surf breaks.

Surfing magazines have always been the major form of media though which images of people and place circulate among surfers. These magazines range from general interest magazines like Surfer to special interest magazines like Pacific Longboarder, and they are distributed through subscriptions and through sales at newsagents and surf shops (Buckley 2006, 453; see also Ponting 2009). All surfing magazines have information on contests and on the celebrity surfers who participate in these events, stories about surfing localities and destinations, and advertisements (Buckley 2006,453 ). All three of these components are heavily illustrated with photographs taken by professional surf photographers (Buckley 2006, 453).

Like most places in the Pacific, coastal peoples in Papua New Guinea recount historic stories about riding waves in canoes, on housing timbers, and on other flat bits of wood. There was not, however, the kind of stand-up surfing that most people practice today until the I960s and I970s, when Australians working for the colonial government brought manufactured surfboards to the Australian colony. After independence, by the early I980s, both Papua New Guineans and expatriates were surfing the breaks near Port Moresby, Vanimo, and Kavieng in earnest. By the late I980s, these surfers had established the Surfing Association of Papua New Guinea (SAPNG), a national body meant to regulate the industry and develop strategies for how surfing might contribute to the Papua New Guinea economy. By the mid-I990s, after legal incorporation in December I996, the association was sponsoring national surfers in the South Pacific Games and the Oceania Indigenous Surfing Competition.

Because of the growing interest in Papua New Guinea as a surf-tourism destination, in April 2006 the Surfing Association of Papua New Guinea presented the Pacific Enterprise Development Facility of the International Finance Corporation with a proposal for the development of a national "surf management plan." In both Vanimo and Kavieng, the local surf clubs had already established local "management plans." The local plans do three things. First, they limit the number of surfers permitted in the water 
at any one time. Second, they charge a levy on each surfer for each day surfed and distribute this money back to the communities who hold the area surf breaks in traditional marine tenure. Third, they provide a small income for the local surf clubs, which is intended to help them develop and promote the local surfers.

The Surfing Association of Papua New Guinea has ten goals, and the development of local "management plans" is meant to help them meet several of them. According to one SAPNG board member, the plans are meant to "promote sustainable development of the industry and make sure that locals get some benefit from it." 4 Additionally, although stated outside of the official SAPNG rhetoric, the plans are meant "to make sure we don't become another Indonesia, with overcrowded breaks and too many international operators taking advantage." The SAPNG plan is the first and only national surf management plan in the world.

Prior to the adoption of the country's surf management plan, between I 987 and 2003, Papua New Guinea was profiled as a surf-tourism destination in the following print magazines: Pacific Longboarder, Surfing Life (three times), Surfers Trip (three times), Ningini Blue (three times), Paradise Magazine (six times), Surf Trip, Surf Europe, Blue Edge Magazine, Island Business, Surf I, and Sports Scope. Since 2004, it has been profiled in Surfing Magazine, Gold Coast Surf, Surfing Life, Surfer Magazine, The Surfers Journal, Surf Magazine, Island Business, Tracks: The Surfers' Bible, and Surfline's Water. Since I980, it has also been covered in seventy-three newspaper stories. The vast majority of these magazines cast Papua New Guinea as exotic, undiscovered, primitive, wild, lost, and beautiful and the men who surf there as intrepid explorers and discoverers of new waves.

\section{Mediated Images}

Tourism takes standard forms that rely in part on mediated images. Contemporary scholars of tourism often use John Urry's notion of the "hermeneutic circle" of tourism to analyze the relationship between images, forms, and actions (2002; see also Caton and Santos 2008; Jenkins 2003). For Urry, tourism is a social form that is based on the visual consumption and reproduction of images (2002, I35). Images circulate, they are imbued with certain meanings, and then these meanings are shared through further circulation (Urry 2002; see also Hall 1997). These images drive touristic desires and practices. In his analysis of images and surf tourism, 
drawing on Urry, Jess Ponting argued that images are transmitted to tourists through surf-related media, that these images inspire travel, that the tourists work to find "the icons of symbolic elements seen in the projected images" and record them themselves, and that finally, the tourists display their own images in ways that work to inspire others to travel (2009,I76; see also Preston-Whyte 2002, 3I3). Ponting called the surf images "nirvanic" and showed, with ethnographic material from the Mentawai Islands of Indonesia, that mediated images of perfect waves, uncrowded conditions, soft adventure, and exotic, tropical environments drive surf tourism there. Ponting also showed that tourism operators know exactly what images they need to produce, on the ground, to enhance the tourism experiences of their guests. They are conscious of the media images and work diligently to make sure that the surfers' experiences mirror the ideals of the media-induced fantasy (Ponting 2009, I78-1 82).

These touristic images are tied to older images of people and places. Miriam Kahn examined the ways in which both colonial and postcolonial images have worked to produce space and place in the Pacific Islands in general and in Tahiti specifically (20II). Tahiti is not just imagined as exotic and tropical, as much of the Pacific is; it is the site of origin for the exotic and the tropical, for European ideas about utopian worlds populated by noble savages living in harmony with nature, and for the dusky maidens that have fueled the sexualized fantasies of Europeans since the I700s (Kahn 20II, 32-60). Kahn showed that for the contemporary tourists who visit because of these fantasies, only certain kinds of activities and images are allowed into their already existing fantasy formations of space, place, nature, and culture. They literally do not see places, peoples, and events that sit outside of the fantasy. This is in part because of the ways that tourism operators structure experience and in part because of the limited field of vision of the tourists. Kahn showed, very clearly, that tourists and Tahitians live in "parallel, but disconnected, worlds" (2OI I, I 5).

Touristic fantasy and image are intertwined with modernist ideas about temporality. David Lipset and Rupert Stasch have both used M M Bakhtin's notion of the "chronotope" to examine spatiotemporal understandings and representations of peoples living in New Guinea (see Bakhtin I98I). ${ }^{5}$ Bakhtin argued that a chronotope is "the intrinsic connectedness of temporal and spatial relationships that are artistically expressed in literature" (I98I, 84). Writers create worlds that reflect the spatiotemporal reality of their own worlds, or at least of how they experience their worlds. In his analysis of the circulation of the figure of the primitive in print media, 
Stasch used the chronotope to describe the multiple scales of spatiotemporal understanding that are displayed in travel writing (20II). The important part of Stasch's work for this argument is what he called the "mythic chronotope" or the "mythic relation between contrasting primitive and civilized humans" (2OI I, 3). This chronotope maps a spatiotemporal scale that mirrors notions of unilinear evolution and forms a set of ingrained ideas and images concerned with the relationship between modern media consumers like tourists and people like the indigenous inhabitants of New Guinea who are considered "primitive" by that first group (Stasch 20II, 6-9). Stasch followed this chronotope and the images it relies on, produces, and reinforces as those images circulate and argued that their repetitiveness makes them persuasive and that their persuasiveness helps to drive primitivist tourism desire.

Lipset's recent work shows clearly that chronotopes are more than just a "category" or helpful "unit of analysis" for ordering events in time and space; they actually engender action and agency (2OII, 2I). He argued that in sites where modernist institutions may or may not have the grounding and solidity that they have in sites in the global north, rival chronotopes may emerge and give rise to "rival chronotopic claims about human agency in time and space" (Lipset 2OII, 2I). Through his analysis of climate-related events and ideas in Papua New Guinea, he showed that rival claims about agency then drive particular kinds of actions and the unfolding of events in a particular sequence in particular places.

Tourism is also driven by other kinds of fantasies about subjectivity and place. In discussing the psychological work that our imagination of "the frontier" does for us, Vincent Crapanzano developed the idea of "the beyond" (2004). For Crapanzano, frontiers are imaginative formations that offer up a set of images of self and trigger a strong set of desires. People strive to reach these desired places and things and the desired selves that we associate with them, but they are always out of reach (Crapanzano 2004, I4). They exist in a place of full fantasy, and once we access a real place, object, or set of interactions that we imagined previously, "the beyond" has moved a tiny bit forward, causing us to always have a melancholic longing for something more.

\section{Australian Fantasies}

Surfing is an indigenous practice in Moana (Pacific Ocean) societies. ${ }^{6}$ The locality best known for a documented history of surfing is Hawai'i. Most 
scholars trace the first European description of surfing to Captain James Cook at Kealakekua Bay in $\mathrm{I788}$, but this description is short and tells only what Cook saw, not anything about why the surfers were surfing. The indigenous newspapers of Hawai' $i$, published in the Hawaiian language, had numerous descriptions of surfing and many accounts of the ways in which the practice was part of a larger social system of ontology and epistemology (see Finney 1996; Nendel 2009; Walker 2008). In Hawai'i, surfing brought together art and artistic production, spirituality, aesthetics (in the sense of bodily experiences), and a set of propositions about the relationships between nature and culture.

Board surfing came to Australia in I9I4 when Duke Kahanamoku, the famous Olympic swimmer from Hawai $i$, visited the country (Booth 2002, 36; Walker 2008). On 23 December, he gave the first public demonstration of surfing at Freshwater Beach, just beyond the Sydney Harbor (Booth 2002, 38). His trip was part of the beginning of a colonial refashioning of Hawai'i and "Hawaiian culture" by nonindigenous promoters who sought to grow the tourism industry there (Trask 1993; Nendel 2009)..$^{7}$ In Australia, after Kahanamoku's demonstration, surfboards were initially, albeit hesitantly, associated with lifesaving as rescue craft, but many people shied away from surfing because it was thought to be "a hedonistic practice" derived from exotic and "other" Hawaici and was considered "menacing" for beach bathers (Booth 2002, 39). However, by the I930s, the Surf Life Saving Association had incorporated boards into their rescue-related paraphernalia, and by 1946 surfboard paddling was included in the national surf lifesaving titles contest (Booth 2002, 87). This sanctioned use of boards was part of a seemingly wholesome and healthy set of practices undertaken by a set of seemingly wholesome and healthy young men-men who were concerned with personal fitness and the safety of Australia's beaches.

In the I950s in Australia, the post-World War II boom "produced a generation of overstimulated over-consumers that looked for continuous thrills and fun" (Booth 2002, 9I). These young people consumed the images of surfing from California and Hawai'i rapaciously (Booth 2002). The I959 movie Gidget (based on a I957 book by Frederick Kohner that recounted the real-life exploits of his daughter, Kathy Kohner, a Malibu teenager who learned to surf from and spent time with well-known Malibu surfers Miki Dora, Terry "Tubesteak" Tracey, Billy "Moondoggie" Bengston, and Bill Jenson) solidified the image of surfers as off-the-grid, anti-mainstream, laid-back pranksters (Rutsky I999). The film portrayed 
surfing as an alternative lifestyle while at the same time making it appeal to postwar, middle-class desires for consumer culture (Booth 2002; see also Cohen 2003). This and other surf-related films sent the message that surfing was a form of "freedom" (Ford and Brown 2006, 59). For example, the 1964 movie Endless Summer conflated travel, youth, freedom, and the search for "the perfect wave" with a narrative of discovery (Orm$\operatorname{rod} 2005,42$ ). The films also created a sense of the "appeal of surfing and surf subculture" that is "based on the attractiveness of nonconformist, irreverent, and anti-bourgeois attitudes cobbled together from elements of teenage culture, rock-and-roll, bohemian philosophy, and beat culture and mixed with a heavy dose of parody" (Rutsky I999, I3).

These films made their way to Australia, as did less mainstream films made by surfers. The films portrayed young men "who rode waves and traveled endlessly, and who never worked or worried," and with this they "carried the potentially subversive message that surfers were less predictable, less trustworthy, and not so ready to fall in line" (Booth 2002, 95). In the late I950s, Greg Noll and other well-known surfers brought Malibu boards to Australia and helped to diffuse even more films and the images in them to the country. ${ }^{8}$ By 1962, Sydney surfer Bob Evans was making his own surf movies, screening them around Sydney, and founding Surfing World, ${ }^{9}$ a publication meant to publicize his films. Surfing World morphed into the magazine Surfer, which by 1970 had a monthly circulation of 100,000 (Booth 2002, 96).

In the late I960s, attitudes toward surfers in Australia began to change. In the 1950 os and early I960s, surfers, for the most part, belonged to surf clubs. These clubs were organized around lifesaving, but they were more like homosocial civic clubs. In the mid-r960s, numerous men who were not members of the clubs began to take up surfing. Part of the I96os baby boomers' counterculture worldwide was disillusionment with the state, with corporations, and with other kinds of institutions thought to have power. According to David Harvey (1989, 38) and Douglas Booth (2002), part of this disillusionment was manifested in the embrace of seemingly antiauthoritarian ideals and seemingly iconoclastic habits.

In Australia, one of these "iconoclastic habits" was surfing and "soulsurfing," or "riding waves for the good of one's soul"; this became the mantra for the counterculture surfers (Booth 2002, II2). By the I970s, Australian surfers were representing themselves as "hedonistic," as "unconventional," and as a "subculture," juxtaposing themselves against lifesaving club members who were "conformist" and "establishment 
types" (Stedman I997, 77; see also Pearson 1979). The sport was becoming a site for the self-fashioning of alternative identity, and magazines played a key role in this (Stedman I997).

The pioneers of the Australian surfing industry, the magazines Surfing World and Tracks, used the counterculture to sell magazines and used the magazines to sell the counterculture (Booth 2002, II3; Stedman I997). The seemingly alternative practice was being used to "advance capitalism by pioneering new commodity forms, particularly in music and leisure" (Booth 2002, II 7 ). The images and fantasies that young people attached to the counterculture in Australia were mapped onto the constellation of objects that came to be associated with surfing. And these objects soon became the commodities that were marketed to people as being crucial to their alternative lifestyles (Booth 2002, II7). The surfing "community" that read magazines noticed this, and the I970s and early I980s saw numerous letters to the magazine editors complaining about people buying the image without understanding the lifestyle (Stedman I997, 80).

By the mid-I970s, most of the world's best known surfing counterculture figures were taking part in international surfing contests that were sponsored by big corporations. By the I 980 s, these contests were a crucial part of surfing-as-sport, and they were directly tied to the marketing of surf-related commodities such as mass-produced boards, clothing, wetsuits, and other items. As all of these aspects of the industry grew, so did surf tourism, and they were all promoted by surf magazines. At the same time, the companies that were commodifying every aspect of surfing were selling rejections of commodification back to the community in the form of alternative "lifestyle choices" (Stedman I997, 8I; Lanagan 2002). As surfers grew uneasy with the fact that by buying a T-shirt or a factory-produced board or by reading a magazine one could identify as a "surfer" - as well as with the fact that almost all of the professional surfers with corporate sponsorship were highly skilled athletes and not "alternative" figures-the surfing companies began to market products, magazines, and experiences for the "authentic" and "alternative" surfers (Stedman 1997; Wheaton 2005).

The surf magazines also provided a basis and constant referent for selffashioning (Stedman 1997, 77). They fostered a sense of community, created and policed the boundaries of the subculture, encouraged the notion that they provided a forum for communication among members of the subculture, and became "the most important site for the maintenance of collective identity" (Stedman I997, 78; see also Ford and Brown 2006, 
59). Magazines are so important that definitions of who is and who is not part of the surfing subculture now depends not on who surfs but on who is portrayed and represented in the specialist surf media. As Leanne Stedman said, "It can now be argued that the subculture as it is simulated through magazines and films is the surfing subculture" $(1997,78)$.

Today, while there are young people learning to surf in record numbers, the population of surfers who travel is growing older and becoming wealthier (Buckley 2006, I94). Because of crowding at mainland surf breaks in Australia and the United States (the two nations with the largest number of surfers), these older, wealthy surfers are creating an increasing demand for overseas surf holidays. ${ }^{10}$ In the South Pacific, the major destination for Australian surfers, this has resulted in the growth of the surf-tourism industry. While there are some small-scale surf travelers who travel to surf but stay in local accommodations and use mainstream transportation, the vast majority of the industry today is organized by specialist surf-tour companies who sell packages to prime locations via live-aboard charters or through specialist surf resorts (see Buckley 2006, I93-195).

\section{UNTOUCHED WORLDS}

Back to the vomiting teenager with whom I began this article: Brendan and his fellow surf tourists came to Papua New Guinea to surf waves that they, as a group, described as "empty" and "pristine" and to interact with people whom Brendan's father described as living "a simple life without the headaches of modernity" and whom one of his friends described as "primitive" and "simple." They also wanted to interact with other surfers who understood that an authentic or real "surfing vibe" can still be found in places like Papua New Guinea.

Brendan's father and his lifelong friends have been taking surfingrelated holiday trips together for twenty years and have been on surf holidays to Australia, New Zealand, California, Hawai'i, Bali, the Mentawis, the Maldives, Sri Lanka, and Costa Rica. They are between the ages of forty-five and sixty, and their occupations range from owner of franchise restaurants, to chief executive officer of a major company, to electrician. They all met through Brendan's father, and unless there is some family or business emergency they go surfing together for two weeks, twice a year, every year. They leave their wives and girlfriends at home. The older men had converged on Nusa Lik Island previously; however, 2007 was the first time they brought their sons. Brendan and one of the other young men 
had just graduated from secondary school, and they were taking a year off before attending university. Everyone considered the trip a sort of comingof-age celebration for the young men. All of these men, both young and old, expressed fantasies about place, people, and time when they described what drew them to Papua New Guinea, what they found when they got there, and why what they found was valuable. Their attitudes exemplified those of almost all of the surf tourists I have interviewed during my research.

The first way that surf tourists expressed their understandings of place to me was through their discussion of the "village" they lived in while in New Ireland. For the surfers described above, that "village" is the Nusa Island Retreat. In 2007, it was a set of ten tourist-ready bungalows, two shower blocks that included self-composting toilets, a main office that doubled as the owners' house, and a restaurant and bar building located on Nusa Lik Island and about a five-minute boat ride from the main port in Kavieng. In addition to the retreat, there is also a local settlement on the island. It is separated from the retreat by a fence.

The "village" experience of the tourists is free from children, pigs, chickens, and the constant stream of activities that make up social life in Papua New Guinea. It is quiet, with manicured tropical plants and with rescued tropical birds populating the trees. Its inhabitants are all workers. They are English-speaking Papua New Guineans who are paid to be friendly, happy, and interested in the tourists. The vast majority of tourist interactions with the staff are with the expatriate surf guide, the boat drivers, and the bartenders. All of these men maintain the "it's all good" attitude with guests at all times. Tourists experience all of this in predictable ways. In interviews, many tourists discussed village life as "laid-back," "chilled out," "easy," "fun," "beautiful," "natural," and "quiet." However, many of them drew temporal conclusions from their experience. One of Brendan's father's friends expressed this when he told me that people living in New Ireland were living "like people lived a thousand years ago."

Place was also discursively produced in terms of the surf breaks, the environment, and Papua New Guinea as a nation-state. The surf breaks were described by one visitor as "undiscovered breaks where nobody but the locals have ever surfed before," and they were valued by the majority of surfers because only a limited number of surfers were allowed on them at any one time. The number of surfers on a given break was the key factor in discussions about them. As one fifty-year-old man described it to me, being "practically alone" on a break fulfilled the fantasies of these 
lifelong surfers. They all expressed to me the frustration they've felt surfing these days in Australia. This was connected back to the "locals" in Papua New Guinea. Elsewhere, breaks are too crowded and there is often a "locals only" mentality there that privileges people who surf the breaks daily and marginalizes visitors. But this is nothing, they argued, compared to the "locals only" mentality that exists in Hawai'i and that is emerging in Indonesia. Hawaiian and Indonesian surfers were accused by many of having a "tribal mentality," while Papua New Guinean surfers were admired for their growing ability (Jim, a forty-two-year-old man from Sydney, said, "Some of these kids will be hot one day," and "There is some real raw, primal talent here"); they were also admired because they have, according to numerous interviewees, maintained their "traditional" way of life. This discursive production of Papua New Guinea and its inhabitants was often expressed just prior to some sort of caveat about the place as "the last frontier," "feral," or having, according to a businessman from Perth, "a feel like the wild wild West . . . where anything can happen." What this meant to the surfers was that you had to be a particular kind of person to embark on the journey to Papua New Guinea.

This assumed maintenance of "tradition" also connects to the environment that surfers find in Papua New Guinea. Tourists described it as an "untouched paradise," as "an aquatic Eden," and as a place where people have not "squandered their resources" or "overused their resources." Again, for many interviewees this was given a temporality. A twenty-six-year-old man from Australia's Sunshine Coast said, "Papua New Guinea is like the last place in the world. It is the last place without development," but one of his friends quickly added, "Yeah, but it is totally threatened." When I asked what he meant by that, they both agreed that there was a worry that Papua New Guinea would develop too fast and that locals wouldn't be ready for "modernity." ${ }^{11}$ With this, images of the environment connected with images of natives; both were cast as being in danger. The danger at hand was variously cast as modernization or development.

Contemporary Islanders were thought to be living in authentic and traditional ways that reflected the ways that their ancestors lived. Repeatedly tourists told me that people there live practically like they did in the Stone Age and that by falling to the corrupting influence of money they would lose their idyllic ways of life. ${ }^{12}$ By taking up the desire for commodities and what one man from Melbourne called "Western bullshit," natives were cast as in danger of destroying their communities and their environ- 
ments. They were also depicted as unready for development and in need of what an Australian aid worker-surfer called "a helping hand to navigate the complex modern world." Thirty-seven of the surfers interviewed used the phrase "they are not ready yet" in their discussions of development in New Ireland. In fact, according to the vast majority of interviewees, the rest of the country already evidenced this. Repeatedly in interviews, New Ireland was with both Port Moresby (the capital of the country, in which none of the surfers spent more than one day) and the Highlands (a region where almost none of the surfers have ever been). These two places were characterized as "dangerous," "rough," "awful," and, for Port Moresby at least, "the asshole of the planet." The people there were seen as violent criminals who have been corrupted by modernity. Surfers thought they stole, drank, were sick with HIV and AIDS, and were a drain on the Australian government and the taxes of the Australian people.

The people in New Ireland that surf tourists discursively produced are of two types: locals and surfers. There are, however, local surfers and surfer locals. The locals are natives who are thought to live in idyllic villages and pass their days, according to a sixty-year-old man from Darwin, "fishing, fucking, and napping" and who have not been, according to a forty-nine-year-old man from Sydney, "polluted by all that capitalism bullshit." The man from Darwin put it clearly: "Their life is so simple here, like it used to be everywhere. It is what we should all aspire to. They don't have to worry about anything." The man from Sydney asked me, "What do they think about? There is nothing to worry about here-no mortgages, car payments, tax-and they don't talk about anything complex. It's not like they are debating politics or anything!" Papua New Guineans were portrayed as compliant, laid-back, and apolitical in almost all of my interviews, in contrast to people in Hawai' $\mathrm{i}$, Fiji, and "Indo" (Indonesia), where locals were seen to be "heavy" and to have been "polluted." The local surfers in Papua New Guinea were considered authentic in their surfing ability and in their lifestyle, which has not been corrupted by the surf industry as it has been elsewhere. As a sixty-two-year-old man from Sydney told me:

You watch them out there and there is this natural ability. I saw a kid the other day on a broken board and he was hot. He didn't need some fancy board to thrash, he was there with the waves and he was in the zone. I hope that they don't buy into the whole product thing, you know? I mean he was just as good on that old broken board as he would be on a new one. All that gear has really changed the mentality of surfing in Australia and Indonesia. All the kids want 
the gear and don't get the lifestyle. It is about you and the swell and the ocean, not about the gear.

The men that I spent time with in New Ireland and that I interviewed online talked about themselves, as surf tourists, and others who brave Papua New Guinea in order to surf in a standardized set of ways. They portrayed themselves and others in New Guinea as set apart from those who go to easy surf destinations in Australia and the United States and as similar to yet more enlightened about surf tourism than surfers who go to international destinations like Indonesia, Fiji, and Costa Rica. Twenty interviewees used the phrase "doing it for the right reasons," and more than fifty of them discussed travel to Papua New Guinea as, to quote a twenty-four-year-old man from Melbourne, "getting back to what it is really all about." These twenty men, when I followed this line of discussion, said that what it was "all about" was, variously, "being free," "saying fuck you to the man," and not buying into that "Rip Curl, Billabong, industry image." The surfers who traveled to Papua New Guinea also discussed the surfer locals, Australian surfers who live full-time in Papua New Guinea. They were cast as having made profound decisions about "how to live" because they have, according to a man from Coolangatta, "tuned out" and "made the call to live an alternative lifestyle." They are, he continued, "free."

\section{Surfer SELVES}

Globally circulated mass-media images of places and practices shape surfers' expectations, experiences, and understandings of Papua New Guinea. As we can see, media-borne fantasy structures the consciousness of tourists; it limits what they see in part because tour operators draw on it in crafting the experiences offered, and in part because the spaces they experience come to be because of the fantasy. All of this fantasy turns on a set of propositions about time. In Papua New Guinea, this is especially apparent. However, it is not simply the mythic chronotope at play in Papua New Guinea's surf tourism industry, although in what follows I show how crucial this fantasy is to surf tourism. The surfers who come to Papua New Guinea are not just searching for mythic, premodern, primitive culture and nature. They are also searching for a prior and pure self. That self is a combination of the intrepid adventurer and a fantasy formation based on the image of the "soul surfer." It is that search for the 
soul surfer, a character who may or may not have ever existed, that ties together the mythic chronotope; the production of space, place, nature, and culture in Papua New Guinea; surfer self-fashioning; and capital. All of this comes to them, in part, through media.

Surf tourism in Papua New Guinea draws on the mythic chronotope in obvious ways, and on "the beyond" in two less obvious ways that are intimately tied to this mythic chronotope. First, surfers are always looking for the next big thing, the newest place, the unknown or undiscovered site, and the unsurfed spot. This is the "future beyond." They try to find this through surf tourism, and a whole industry around it is being perpetuated by surfing magazines. This industry works to create and sustain this "beyond" but also to make it unattainable at the same time. Part of its unattainability is that it replicates the mythic chronotope, a time/space that people can't really find. It is discursively produced in people's descriptions of Papua New Guinea-what they thought was "the final frontier"-but they know in their heart of hearts that the true, untouched, primitive, and unsurfed break is out there waiting for them on another frontier.

Second, surfers also focus on "the beyond" that is in the past. A sort of authentic surfing of yesterday that was more about the waves and less about the gear, that was more closely tied to "soul surfing," that was populated by fewer people, and that was not polluted by aggressive young surfers. They desire the imagined past—a past that none of them actually experienced, because it never really existed. It was, from the beginning of the surf industry, a product sold to consumers. It is this desire for the "previous beyond" that drives the attempts to access the "future beyond."

Counterculture identity draws on an imagined past that is supposedly more authentic and pure than the present. The music, the clothing, the things people had, and what people did have supposedly been polluted today by capitalism and commodification. But when people reference this supposedly authentic past, they do so through the very commodities that made surfing what it is today-by talking about alternative brands or alternative contests or alternative destinations, like Papua New Guinea. There is a way in which the authenticity that is lamented as lost is just as tied to consumer capitalism as the modernity that is disdained.

The chronotopic fantasies of "the beyond" drive contemporary exploration, and exploration has always led and continues to lead to dispossession. In American Empire, Neil Smith argued that with the closing of absolute space there is a realigning of space and who controls it (2002). When the frontier is closed, new frontiers are opened and new sets of local 
actors are disposed of by the accumulative desires and actions of people with capital and power. The discovery and pushing of the surf-site frontier is a form of accumulation by dispossession or uneven development. Tourism, with its constant production of new illusions of the "further beyond"-sites and frontiers that are not ruined by tourism-is a neverending form of accumulation by dispossession. It is relentless in its search for new images and new destinations; however, these newly discovered places are not really very new at all.

Claims of discovery are really at their base political claims. There is no real discovery going on. By claiming to have discovered something, you are editing out the people who live in a place from your representations of that place and thus attempting to disempower them. This disempowerment, this erasure of people from sea- and landscapes, leads to the fantasy of these sites as empty and therefore open to transformation by outsiders. Surfers see themselves as part of an imagined community (Anderson I983) - part of the "global tribe" and an assumed "ecological nation," a diasporic nation - and they narrate a particular history of that nation. This makes sense insofar as their diaspora nation, like other nations and other circulators of capital, has worked to dispossess people in many places of land- and sea-based rights.

There has been a great deal of discussion in the tourism literature about "authenticity" and the ways in which tourists seek sites where they can experience some sense of it (see West and Carrier 2004). In his early, seminal analysis of the way that the search for authenticity drives tourism, Dean MacCannell argued, "Modern man has been condemned to look elsewhere, everywhere, for his authenticity, to see if he can catch a glimpse of it reflected in the simplicity, poverty, chastity, or purity of others" (I976, 4I). His argument is that the "authentic" that is sought after is not the authentic other (although that is in fact one thing that drives some tourism) but rather an authentic self. Surfers, like most modern Western tourists, assume that the present replaces the past. By discovering places like Kavieng, they can step back into the past and thereby access not only what they assume to be the "prior other" but also what they assume to be a "prior self." The seeming authenticity of the future beyond allows them imaginative access to the "previous beyond." This tourism is not about Papua New Guinea at all; it is about a search for a pure, unpolluted, self. However, this is a self that is the social production of surf magazines, the surf industry, and the very forms of capital that these men attempt to escape from and to deny to the citizens of Papua New Guinea. 
These fantasies endure in part because they sell; their value accrues in the stories that people tell about Papua New Guinea when they get home. These stories give the trip and the place a particular sort of value. People enjoy their trips, but they enjoy telling stories about them even more. My vomiting teenager had already heard fantasy-fueled stories about Papua New Guinea before he visited-from his father and from magazines. And I'm sure he has told many stories of his own over the past few years.

THE TITLE OF THIS ESSAY is drawn from Michael Taussig's 2000 essay "The Beach (A Fantasy)." I presented versions of this paper in Wisconsin, Michigan, Texas, and at several meetings of the Association for Social Anthropology in Oceania. I want to thank the people who attended these talks for their insightful comments.

\section{Notes}

I This article is based in part on twenty-four months of ethnographic work in Papua New Guinea between 2007 and 201 I.

2 During the 2007-2008 surf season, the Kavieng Surf Club sponsored a visitor survey. Of the 239 surveyed, 23 I were from Australia. Twenty were between the ages of IO and I9, twenty were between 20 and 29, sixty-five were between 30 and 39, seventy-four were between 40 and 49 , fifty-two were between 50 and 59 , and six were over 60.

3 Between 2008 and 2012, I conducted e-mail and Skype interviews with forty-five people who had been to Papua New Guinea to surf.

4 All direct quotations in this article are drawn from interview data. All of the names are pseudonyms.

5 See Lipset 1997, 2004, and 2007 for the first use of Bakhtin's ideas about chronotopes and the dialogic in the case of New Guinea.

6 See Warshaw 2oro for a detailed history of surfing.

7 The United States overthrew the queen in I893, and by 1898 it had established itself as the colonial power. In I959, Hawai'i was made a US state (see Kauanui 2008; Tengan 2008).

8 In interviews with Australian surfers in their sixties today, many mention these early "alternative" films and festivals.

9 See http://www.surfresearch.com.au/rm.html for images from the first issues.

Io See Lazarow 2009 and 2007 for analyses of the economic impacts of surfing in Australia today. See Lazarow and others 2008 for an analysis of the social values of surfing in Australia. 
I I The word "modernity" was used repeatedly by surfers I interacted with. It appears 232 times in my interview transcripts and e-mail interviews. I did not use it or bring it up in any of these interviews. It was, in every instance, tied to a lament about what has been lost elsewhere.

I 2 "Stone Age" appears 409 times in my data set.

\section{References}

Anderson, Benedict

I983 Imagined Communities. London: Verso.

\section{Bakhtin, M M}

I98 I The Dialogic Imagination: Four Essays. Translated by Caryl Emerson and Michael Holquist. San Antonio: University of Texas Press.

Beattie, Keith

200I Sick, Filthy and Delirious: Surf Film and Video and the Documentary Mode. Journal of Media and Cultural Studies I 5 (3):333-348.

Booth, Douglas

2002 Australian Beach Cultures: The History of Sun, Sand and Surf. London: Frank Cass.

2005 Paradoxes of Material Culture: The Political Economy of Surfing. In The Political Economy of Sport, edited by John Nauright and Kim-

Buckley, Ralf berly Schimmel, I04-I 23. New York: Palgrave.

2003 Adventure Tourism and the Clothing, Fashion and Entertainment Industries. Journal of Ecotourism 2 (2): I 26-I 34.

2006 Adventure Tourism. Wallingford, UK: САВ International.

Caton, Kellee, and Carla Almeida Santos

2008 Closing the Hermeneutic Circle? Photographic Encounters with the

Cohen, Lisbeth Other. Annals of Tourism Research 35 (I): 7-26.

2003 A Consumers' Republic: The Politics of Mass Consumption in Postwar America. New York: Vintage Books.

Crapanzano, Vincent

2004 Imaginative Horizons: An Essay in Literary-Philosophical Anthropology. Chicago: University of Chicago Press.

Croy, Glen, Warwick Frost, and Sue Beeton

2009 Introduction: Tourism and Media. Tourism Analysis I4 (2): I 53I 54 .

Finney, Ben

I996 Colonizing an Island World. Transactions of the American Philosophical Society (NS) 86 (5): 7I-I I 6. 
Foale, Simon J, and Martha A Macintyre

2005 Green Fantasies: Photographic Representations of Biodiversity and Ecotourism in the Western Pacific. Journal of Political Ecology I2: I-22.

Ford, Nick, and David Brown

2006 Surfing and Social Theory: Experience, Embodiment and Narrative of the Dream Glide. London: Routledge.

Hall, Stuart

I997 Representations: Cultural Representations and Signifying Practices. London: Sage.

Harvey, David

I989 The Condition of Postmodernity: An Enquiry into the Origins of Cultural Change. London: Blackwell.

Henderson, Margaret

I999 Some Tales of Two Mags: Sports Magazines as Glossy Reservoirs of Male Fantasy. Journal of Australian Studies 23 (62): 64-80.

Jenkins, Olivia $\mathrm{H}$

2003 Photography and Travel Brochures: The Circle of Representation. Tourism Geographies 5 (3): 305-328.

Kahn, Miriam

20 I T Tahiti, Beyond the Postcard: Power, Place, and Everyday Life. Seattle: University of Washington Press.

Kampion, Drew

2003 Stoked! A History of Surf Culture. Layton, ut: Gibbs Smith.

Kauanui, J Kēhaulani

2008 Hawaiian Blood: Colonialism and the Politics of Sovereignty and Indigeneity. Durham, NC: Duke University Press.

Lanagan, David

2002 Surfing in the Third Millenium: Commodifying the Visual Argot. The Australian Journal of Anthropology I3 (3): 283-29I.

Lazarow, Neil

2007 The Value of Coastal Recreational Resources: A Case Study Approach to Examine the Value of Recreational Surfing to Specific Locales. In Proceedings of the 9th International Coastal Symposium, Gold Coast, Australia. Special issue of the Journal of Coastal Research 50:1 2-20.

2009 Using Observed Market Expenditure to Estimate the Economic Impact of Recreational Surfing to the Gold Coast, Australia. In Proceedings of the Ioth International Coastal Symposium, Lisbon, Portugal. Special issue of the Journal of Coastal Research 56:I I 30I I34. 
Lazarow, Neil, Marc L Miller, and Boyd Blackwell

2008 The Value of Recreational Surfing to Society. Tourism in Marine Environments 5 (2/3): I45-I 58 .

Lipset, David M

I997 Mangrove Man: Dialogics of Culture in the Sepik Estuary (Papua New Guinea). Cambridge: Cambridge University Press.

2004 Modernity without Romance? Masculinity and Desire in Courtship Stories Told by Young Papua New Guinean Men. American Ethnologist 31:205-224.

2007 Women without Qualities: More Courtship Stories Told by Papua New Guinea Youth. Ethnology 46:93-I I I.

20I I The Tides: Masculinity and Climate Change in Coastal Papua New Guinea. Journal of the Royal Anthropological Institute I 7:20-43.

MacCannell, Dean

I976 The Tourist: A New Theory of the Leisure Class. New York: Schocken Books.

Nendel, Jim

2009 Surfing in Early Twentieth-Century Hawai'i: The Appropriation of a Transcendent Experience to Competitive American Sport. The International Journal of the History of Sport 26 (I6): 2432-2446.

Ormond, Joan

2005 Endless Summer (1964): Consuming Waves and Surfing the Frontier.

Pearson, Kent Film and History 35 (I): 39-5 I.

I979 Surfing Subcultures of Australia and New Zealand. St Lucia: University of Queensland Press.

Ponting, Jess

2009 Projecting Paradise: The Surf Media and the Hermeneutic Circle in Surfing Tourism. Tourism Analysis I4 (2): I75-I 85 .

Preston-Whyte, Robert

2002 Constructions of Surfing Space at Durban, South Africa. Tourism Geographies 4 (3): 307-328.

Reed, Michael Alan

I999 Waves of Commodification: A Critical Investigation into Surfing Subculture. MA thesis, San Diego State University.

Rutsky, R L

I999 Surfing the Other: Surf Films from the I950s, I960s and How Teenagers Responded. Film Quarterly 52 (4): I 2-23.

Smith, Neil

2002 American Empire: Roosevelt's Geographer and the Prelude to Globalization. Berkeley: University of California Press. 
Stasch, Rupert

20I I Textual Iconicity and the Primitivist Cosmos: Chronotopes of Desire in Travel Writing about Korowai of West Papua. Journal of Linguistic Anthropology 2 I (I): I-2I.

Stedman, Leanne

I997 From Gidget to Gonad Man: Surfers, Feminists and Postmodernism. The Australia and New Zealand Journal of Sport 33 (I): 75-90.

Taussig, Michael

2000 The Beach (A Fantasy). Critical Inquiry 26 (2): 249-278.

Tengan, Ty P Kāwika

2008 Native Men Remade: Gender and Nation in Contemporary Hawai' $i$.

Durham, NC: Duke University Press.

Trask, Haunani-Kay

I999 From a Native Daughter: Colonialism and Sovereignty in Hawai'i.

Revised edition. Honolulu: University of Hawai'i Press.

Urry, John

2002 The Tourist Gaze. Second edition. London: Sage.

Walker, Isaiah Helekunihi

2008 Hui Nalu, Beachboys, and the Surfing Boarder-lands of Hawai'i. The

Contemporary Pacific 20 (I): 89-II3.

Warshaw, Matt

2004 The Encyclopedia of Surfing. Camberwell, vic: Viking, Penguin.

2010 The History of Surfing. San Francisco: Chronicle Books.

West, Paige, and James G Carrier

2004 Getting Away from It All? Ecotourism and Authenticity (with commentary and reply). Current Anthropology 45 (4): 483-498.

Wheaton, Belinda

2005 Selling Out? The Commercialization and Globalization of Lifestyle Sport. In The Global Politics of Sport: The Role of Global Institutions in Sport, edited by Lincoln Allison, I40-I6I. London: Routledge.

unwTo, United Nations World Tourism Organization

20II International Tourism 20I0: Multi-speed Recovery. Press release, Madrid, I7 January.

\section{Abstract}

Both sport and tourism are deeply modernist forms that rely on the circulation of people, media, and capital for their endurance. In this article, I analyze both forms through the ethnographic examination of surf-related tourism in Papua New 
Guinea. For many Papua New Guineans, surf tourism is an avenue for gaining positions in wage labor. For some the development of the industry is an attempt to foster "sustainable" economic development in the country. These forms of participation rely on international tourists who see the sport and the industry in Papua New Guinea as a site for recreation and play. This article deals with these people, surf tourists who visit Papua New Guinea and for whom surfing is a major part of their social identity. Surfing as an embedded, affective practice and a set of deeply socio-ecological propositions about people-in-nature is historically tractable to indigenous Pacific Island societies. It was deterritorialized, or removed from the context of its origin, by Australian and American youth who took up the practice as a sport in the early part of the twentieth century. Today surfing has been reassembled as a form of development in the very places from which it emerged. Through the analysis of the movements of media, people, and capital involved in the surf tourism industry in Papua New Guinea, this article demonstrates the new social assemblages that emerge when labor, development, and play intertwine.

KEYWORDS: tourism, Papua New Guinea, fantasy, sport, development 